\title{
Pengelolaan Dana Desa Di Kampung Badonggwan Distrik Sausapor Kabupaten Tambrauw
}

\author{
Joseph E Lopulalan ${ }^{1 *}$, Aram Palilu ${ }^{2}$ \\ Universitas Victory Sorong \\ 'josephlopulalan@gmail.com
}

\begin{abstract}
Abstrak
Pengelolaan Dana Desa yang dilakukan di Kampung Bandonggwan Distrik Sausapor Kabupaten Tambrauw belum optimal demi kesejahteraan rakyat karena minimnya Sumber Daya Manusia yang dimiliki Kampung Bandonggwan khususnya dalam keahlian perencanaan, akuntansi dan komputerisasi. Pandemik Covid-19 menyebabkan Pengelola Dana Desa dan Pemerintah Kampung Bandonggwan untuk merevisi APBKam dengan memprioritaskan penggunaan dana desa untuk mempertahankan taraf ekonomi masyarakat dan upaya pencegahan penyebaran Covid-19. pengelolaannya dapat berjalan karena didukung oleh pendampingan dari Pemerintah Distrik Sausapor maupun Pemerintah Kabupaten Tambrauw. Guna memperoleh informasi bagi penelitian ini, maka sampel ditarik berdasarkan tujuan dan pertimbangan kepentingan penelitian (Purpossive Sampling) sehingga dapat mewakili setiap bagian sampel penelitian dimana pengelolaan Dana Desa di Kampung Badonggwan Distrik Sausapor Kabupaten Tambrauw dilaksanakan. Adapun data diperoleh dari 6 (enam) orang informan yang terkait dengan pengelolaan dana desa di Kampung Bandonggwan Distrik Sausapor Kabupaten Tambrauw. Selain data yang diperoleh dari para informan, ada juga data penelitian yang diperoleh melalui observasi yang dilakukan peneliti terhadap objek penelitian selama 24 hari kerja. Guna mengoptimalkan pengelolaan Dana Desa terkhusus dengan karakteristik daerah pemekaran baru maka penelitian ini menyarankan kepada Pemerintah Kabupaten Tambrauw maupun Pemerintah Distrik Sausapor untuk memprogramkan kegiatan peningkatan kapasitas pemerintah kampung dalam penguasaan komputer dan pelatihan akuntansi/pembukuan dan perencanaan program guna menyiapkan kader pengelola administrasi dan keuangan di setiap kampung dalam wilayah pemerintahannya.
\end{abstract}

Kata kunci: Pengelolaan Dana Desa, ADD

\section{Village Fund Management in Kampung Badonggwan Sausapor District, Tambrauw District}

\begin{abstract}
The management of Village Funds carried out in Bandonggwan Village, Sausapor District, Tambrauw Regency has not been optimal for the welfare of the people due to the lack of Human Resources owned by Kampung Bandonggwan, especially in planning, accounting and computerization skills. The Covid-19 pandemic caused the Village Fund Managers and the Bandonggwan Village Government to revise the APBKam by prioritizing the use of village funds to maintain the economic level of the community and efforts to prevent the spread of Covid19. Its management can run because it is supported by assistance from the Sausapor District Government and the Tambrauw Regency Government. In order to obtain information for this research, the sample was drawn based on the purpose and consideration of research interests (purposive sampling) so that it could represent every part of the research sample where the management of the Village Fund in Badonggwan Village, Sausapor District, Tambrauw Regency was implemented. The data were obtained from 6 (six) informants related to the management of village funds in Bandonggwan Village, Sausapor District, Tambrauw Regency. In addition to the data obtained from informants, there is also research data obtained through observations made by researchers of the object of research for 24 working days. In order to optimize the management of the Village Fund, especially with the characteristics of the newly created regions, this study suggests the Tambrauw Regency Government and the Sausapor District Government to program activities to increase the capacity of the village government in computer mastery and training in accounting / bookkeeping and program planning to prepare administrative and financial management cadres in each. village within the territory of his administration.
\end{abstract}

Keywords: Village Fund Management, ADD. 


\section{PENDAHULUAN}

Dana Desa (DD) sampai saat ini masih menjadi isu penting dan mendapat perhatian, baik oleh pemerintah maupun masyarakat, karena selain menggunakan sumber dana dari APBN, juga diperlukan bagi peningkatan kesejahteraan dan pemerataan pembangunan masyarakat desa. Begitu besarnya 'Dana Desa yang dianggarkan APBN menyebabkan Dana Desa menjadi rawan ditunggangi kepentingan politis untuk pemilu dan pemilukada dan tingginya potensi korupsi di daerah ( Direktorat Litbang KPK, 2015), karena semakin banyak desa yang dimiliki daerah, maka semakin besar Dana Desa yang diterima pemerintah daerah.

Pembagian Dana Desa, didasarkan pada jumlah desa (ayat 1), tingkat kesulitan geografis (ayat 3) dan jumlah penduduk, luas wilayah, angka kemiskinan, serta indeks kemahalan (ayat 4, Pasal 11, PP No. 22 Tahun 2015 tentang Dana Desa Yang bersumber dari APBN). Namun realisasinya, $90 \%$ dibagi rata ke semua desa dan $10 \%$ memperhitungkan variabel. Jadi semakin banyak desa yang dimiliki daerah, maka semakin besar Dana Desa yang diterima. Dengan demikian, semakin besar pula pertanggungjawabannya.

Keuangan desa seharusnya dikelola berdasarkan asas-asas transparansi, akuntabel, partisipatif serta dilakukan dengan tertib dan disiplin anggaran (Permendagri No. 113 Tahun 2014, Bab II, Pasal 2). Namun kenyataannya prinsip tata kelola tersebut, belum mampu diimplementasikan dengan baik oleh setiap desa, sehingga pengelolaan Dana Desa menjadi tidak efektif. Astri Furqani (2010) menemukan bahwa dalam manajemen keuangan Desa Kalimo Kecamatan Kalianget Kabupaten Sumenep, hampir semua proses tidak memenuhi prinsip akuntabilitas karena dalam proses terdapat beberapa hal yang tidak sesuai dengan Permendagri Nomor 37/2007. Masyarakat dan BPD (Badan Permusyawaratan Desa) tidak dilibatkan, sedangkan asas transparansi hanya diterapkan pada tahapan perencanaan saja. Penelitian lain oleh Farida (2015:118) menunjukkan bahwa penyebab akuntabilitas rendah pengelolaan keuangan desa adalah faktor SDM, karena pengelola belum mampu membuat pertanggungjawaban administrasi keuangan. Demikian pula yang terjadi di Kecamatan Dolo Selatan, Kabupaten Sigi, ternyata pertanggungjawaban administrasi keuangan belum baik, sehingga masih diperlukan pendampingan dari aparat pemerintah daerah (Ade Irma, 2015:136).

Bertolak dari beberapa penelitian awal dengan substansi kajian seputar pengelolaan
Dana Desa dikaitkan dengan konteks kurangnya Sumber Daya Manusia (SDM) untuk memimpin pemerintahan di kampung-kampung pada daerah-daerah pemekaran baru di Provinsi Papua Barat sehingga penggandatugasan Aparatur Sipil Negara (ASN) yang bertugas di tingkat distrik sebagai pimpinan pemerintahan di kampung-kampung dalam wilayah pemerintahan distrik tersebut menjadi kebijakan untuk memfasilitasi pemekaran daerah tersebut merupakan alasan dilakukannya penelitian dengan judul "Pengelolaan Dana Desa Di Kampung Badonggwan Distrik Sausapor Kabupaten Tambrauw".

\section{LANDASAN TEORI}

\subsection{Pengertian Desa}

Desa adalah kesatuan masyarakat hukum yang memiliki batas wilayah yang berwenang untuk mengatur dan mengurus urusan pemerintahan, kepentingan masyarakat setempat berdasarkan prakarsa masyarakat, hak asal usul, dan/atau hak tradisional yang diakui dan dihormati dalam sistem pemerintahan Negara Kesatuan Republik Indonesia (Permendagri No. 113 tahun 2014, Bab I, Pasal 1, ayat 1).

Desa atau yang disebut dengan nama lain telah ada sebelum Negara Kesatuan Republik Indonesia terbentuk. Dalam penjelasan Pasal 18 Undang-Undang Dasar Negara Republik 2014 tentang Pemilihan Kepalan Desa, Pemendagri Nomor 113 Tahun 2014 tentang Pedoman Pengelolaan Indonesia Tahun 1945 (sebelum perubahan) menyebutkan bahwa "Dalam teritori Negara Indonesia terdapat lebih kurang 250 "Zelfbesturende landschappen" dan "Volksgemeenschappen", seperti desa di Jawa dan Bali, Nagari di Minangkabau, dusun dan marga di Palembang, Kampung di Papua dan Papua Barat, dan sebagainya.

Daerah-daerah itu mempunyai susunan asli dan oleh karenanya dapat dianggap sebagai daerah yang bersifat istimewa. Negara Republik Indonesia menghormati kedudukan daerahdaerah istimewa tersebut dan segala peraturannya. Oleh sebab itu, keberadaannya harus (wajib) diakui dan diberikan jaminan keberlangsungan hidupnya dalam Negara Kesatuan Republik Indonesia (Landasan UU Nomor 6 Tahun 2014). Desa memiliki hak asal usul dan hak tradisional dalam mengatur dan mengurus kepentingan masyarakat setempat dan berperan mewujudkan cita-cita kemerdekaan berdasarkan Undang-Undang Dasar Negara Republik Indonesia Tahun 1945. 
Kini Desa telah berkembang sesuai dengan bentuknya. Oleh karena itu, untuk menjadi Desa yang kuat, maju, mandiri, dan demokratis, perlu dilindungi dan diberdayakan. Hal ini, agar tercipta masyarakat yang adil, makmur, dan sejahtera. Pembangunan Desa, sejak dulu "tertinggal", sehingga tujuan masyarakat yang adil, makmur dan sejahterapun jauh tertinggal.

Semenjak periode kepemimpinan pertama Presiden Joko Widodo (periode 2014-2019), Desa menjadi salah satu perhatiannya dalam pembangunan. Salah satu kebijakan Jokowi yang mengatasnamakan kepentingan peningkatan pembangunan di lini terdepan bangsa yakni desa adalah pemberian Dana Khusus kepada Desa melalui Pemerintah Desa seluruh Indonesia yang disebut dengan Dana Desa.

\subsection{Dana Desa}

Dana Desa (DD) adalah dana yang bersumber dari Anggaran Pendapatan dan Belanja Negara (APBN) yang diperuntukkan bagi Desa yang ditransfer melalui Anggaran Pendapatan dan Belanja Daerah Kabupaten/ Kota dan digunakan untuk membiayai penyelenggaraan pemerintahan, pelaksanaan pembangunan, pembinaan kemasyarakatan, dan pemberdayaan masyarakat (Permendagri No. 113 tahun 2014, Bab I, Pasal 1, ayat 9). Sedangkan Alokasi Dana Desa yang dikenal dengan ADD merupakan bagian dari keuangan desa (APBDes) yang bersumber dari APBD (kabupaten /kota).Tujuan Dana Desa adalah meningkatkan kesejahteraan dan pemerataan pembangunan desa melalui peningkatan pelayanan publik di desa, memajukan perekonomian desa, mengatasi kesenjangan pembangunan antar desa serta memperkuat masyarakat desa sebagai subjek dari pembangunan.

Peraturan yang terkait dengan Desa dan Dana Desa diatur oleh Undang Undang Nomor 6 Tahun 2014 tentang Desa, Peraturan Pemerintah Nomor 43 Tahun 2014 tentang Pelaksanaan Undang Undang Desa, Peraturan Pemerintah 22 Nomor 8 Tahun 2016 tentang Dana Desa Bersumber dari Anggaran Pendapatan dan Belanja Negara. Sedangkan pelaksanaan teknis untuk Dana Desa diatur oleh Pemendagri Nomor 111 Tahun 2014 tentang Pedoman Teknis Peraturan Desa, Pemendagri Nomor 112 Tahun 2014 tentang Pemilihan Kepalan Desa, Pemendagri Nomor 113 Tahun 2014 tentang Pedoman Pengelolaan Keuangan Desa, Pemendagri Nomor 114 Tahun 2014 tentang Pedoman Pembangunan Desa. Pelaksanaan Dana Desa pada level Pemerintahan Desa diatur oleh Permendesa Nomor 1 Tahun 2015 tentang Pedoman
Kewenangan Berdasarkan Asal Usul dan Kewenangan Lokal Berskala Desa, Permendesa Nomor 2 Tahun 2015 tentang Pedoman Tata Tertib Mekanisme Pengambilan Keputusan Musyawarah Desa, Permendes Nomor 3 Tahun 2015 tentang Pendampingan Desa. Aturan yang berkaitan dengan penyaluran, penerimaan, pengeluraran dan pelaporan Keuangan Desa yang berasal dari APBN diatur oleh Kementrian Keuangan melalui Peraturan Menteri Keuangan (PMK) Nomor 241 Tahun 2014 tentang Pertanggungjawaban Anggaran Transfer, PMK Nomor 93 Tahun 2015 tentang Tatacara Mengenai Pengalokasian, Penyaluran, Penggunaan, Pemantauan Dan Evaluasi Dana Desa, PMK Nomor 257 Tahun 2015 tentang Sanksi Dana Desa.

Pengalokasian Dana Desa diatur dan didasarkan (Kementrian Keuangan PMK Nomor 93 Tahun 2015) pada instruksi Direktur Jenderal Perimbangan Keuangan bahwa pengeluaran Dana Desa dialokasikan sebagai Anggaran Dana Desa. Rincian dari kebutuhan Dana Desa yang akan diberikan kepada Desa di seluruh Indonesia, rincian dan perhitungannya menjadi tanggungjawab masing-masing Pemerintah Kabupaten atau Pemerintah Kota yang membawahi jumlah desa masing-masing.

Dana Desa dan Rinciannya yang akan ditransfer oleh Pemerintah Pusat ke Pemerintah Kabupaten atau Kota dialokasikan secara berkeadilan didasarkan pada: (a) alokasi dasar; dan (b) alokasi yang dihitung berdasarkan jumlah penduduk, angka kemiskinan, luas wilayah geografis, dan tingkat kesulitan terutama bidang ekonomi dari masing-masing desa. Rincian Dana Desa yang terdapat pada masing-masing Pemerintah Kabupaten pengalokasiaannya dihitung didasarkan pada: (a) $25 \%$ (dua puluh lima persen) berdasarkan jumlah penduduk, (b) $35 \%$ (tiga puluh lima persen) berdasarkan angka kemiskinan desa, (c) $10 \%$ (sepuluh persen) berdasarkan luas wilayah desa, (d) $30 \%$ (tiga puluh persen) angka kemiskinan dan tingkat kesulitan geografis desa, angka kemiskinan dan tingkat kesulitan desa ditunjukkan oleh jumlah penduduk miskin desa dan IKK (Indeks Kemiskinan dan Kesulitan) pada masing-masing Pemerintah Kabupaten.

\subsection{Penyaluran Dana Desa}

Penyaluran Dana Desa, diatur dalam PMK No. 247 Tahun 2015 tentang Tata cara Pengalokasian, Penyaluran, Penggunaan, Pemantauan dan Evaluasi Dana Desa, Pasal 14, yang berbunyi sebagai berikut:

Ayat 1: Penyaluran Dana Desa dilakukan dengan cara pemindahan buku dari RKUN ke RKUD, selanjutnya dilakukan pemindahan 
buku dari RKUD ke RKD (Rekening Kas Desa).

Ayat 2: Penyaluran Dana Desa sebagaimana dimaksud (ayat 1) dilakukan secara bertahap dengan ketentuan sebagai berikut : Tahap I (bulan April) sebesar $40 \%$, Tahap II (bulan Agustus) sebesar 40\%, Tahap III (bulan Oktober) sebesar $20 \%$.

Ayat 3: Penyaluran Dana Desa pada setiap tahap sebagaimana dimaksud, dilakukan paling lambat pada minggu II bulan bersangkutan.

Ayat 4: Penyaluran Dana Desa dari RKUD ke RKD dilakukan paling lambat 7 hari kerja setelah Dana Desa diterima di RKUD.

Namun saat ini PMK No. 247 Tahun 2015 tentang Tatacara Pengalokasian, Penyaluran, Penggunaan, Pemantauan dan Evaluasi Dana Desa, Pasal 14 di atas, telah dirubah menjadi dua tahap (PMK No 247 Tahun 2016), yaitu: Dari RKUN ke RKUD:

Tahap I sebesar $60 \%$ (bulan Maret) dengan persyaratan: a) Perda APBD tahun anggaran berjalan; b) Perkada mengenai tatacara pembagian dan penetapan rincian Dana Desa di setiap Desa; c) Laporan realisasi penyaluran dan laporan konsolidasi penggunaan Dana Desa tahun lalu.

Tahap II sebesar $40 \%$ (bulan Agustus) dengan persyaratan paling kurang 50\% Dana Desa Tahap I telah disalurkan ke RKD dan laporan konsolidasi penggunaan Dana Desa telah selesai dibuat. Dari RKUD ke RKD : Tahap I sebesar $60 \%, 7$ hari kerja setelah diterima dari RKUN dengan persyaratan : 1) Sesuai Perdes APBDes, 2) Laporan realisasi Dana Desa tahun anggaran sebelumnya Tahap II sebesar $40 \%, 7$ hari kerja setelah diterima dari RKUN dengan persyaratan : a) Laporan penggunaan Dana Desa Tahap I sudah dibuat b) Paling kurang 50\% Dana Desa telah digunakan Dana Desa (DD) yang bersumber dari APBN tersebut, merupakan salah satu sumber pendapatan keuangan Desa yang menjadi bagian dari APBDes.

Realisasi pelaksanaan APBDes harus dilaporkan dan dipertanggungjawabkan kepada bupati/walikota oleh kepala desa. Pelaporan dilakukan sebanyak 2 semester (Juli dan Januari ), sedangkan pertanggungjawaban hanya pada akhir tahun. Oleh karena itu, pemerintah daerah dalam hal ini bupati/walikota juga harus mengelola dengan baik untuk dipertanggungjawabkan.

Dalam konteks pengelolaan keuangan daerah, terdapat tiga prinsip (Mardiasmo, 2002:105) dalam konteks good governance, yaitu :

Prinsip transparansi atau keterbukaan, memungkinkan masyarakat memiliki hak dan akses yang sama untuk mengetahui proses anggaran.

Prinsip akuntabilitas, pertanggungjawaban publik bahwa proses penganggaran mulai dari perencanaan, penyusunan, dan pelaksanaan harus benar-benar dapat dilaporkan dan dipertanggungjawabkan kepada DPRD dan masyarakat.

Prinsip value for money, bahwa prinsip ini berarti diterapkannya tiga pokok dalam proses penganggaran yaitu ekonomis, efisiensi, dan efektif. Sedangkan menurut Permendagri No. 113 Tahun 2014, (Bab II, Pasal 2), keuangan desa seharusnya dikelola berdasarkan asas-asas transparan, akuntabel, partisipatif serta dilakukan dengan tertib dan disiplin anggaran.

\subsection{Pelaporan Dana Desa}

Tatacara Pelaporan Dana Desa dan pertanggungjawabannya dipegang oleh Kepala Desa selaku pemegang kekuasaan pengelolaan keuangan desa. Urutan serta tatacara Pelaporan Dana Desa didasarkan pada Kemendagri No.113 Tahun 2014. Kepala Desa menyampaikan laporan realisasi pelaksanaan APBDesa kepada Bupati/Walikota berupa:

Laporan semester pertama; dan

Laporan semester akhir tahun.

Laporan semester pertama berupa laporan realisasi APBDesa.

Laporan realisasi pelaksanaan APBDesa disampaikan paling lambat pada akhir bulan Juli tahun berjalan. Laporan semester akhir tahun disampaikan paling lambat pada akhir bulan Januari tahun berikutnya.

Kepala Desa menyampaikan laporan pertanggungjawaban realisasi pelaksanaan APBDesa kepada Bupati/Walikota setiap akhir tahun anggaran. Laporan pertanggungjawaban realisasi pelaksanaan APBDesa, terdiri dari pendapatan, belanja, dan pembiayaan. Laporan pertanggungjawaban realisasi pelaksanaan APBDesa ditetapkan dengan Peraturan Desa. Peraturan Desa tentang laporan pertanggungjawaban realisasi pelaksanaan APBDesa dilampiri: (a) format Laporan Pertanggungjawaban Realisasi Pelaksanaan APBDesa Tahun Anggaran berkenaan; (b) format Laporan Kekayaan Milik Desa per 31 Desember Tahun Anggaran berkenaan; dan (c) format Laporan Program Pemerintah dan Pemerintah Daerah yang masuk ke desa. Laporan Pertanggungjawaban Realisasi Pelaksanaan APBDesa merupakan bagian tidak terpisahkan dari laporan penyelenggaraan Pemerintahan Desa.

Laporan realisasi dan laporan pertanggungjawaban realisasi pelaksanaan APBDesa diinformasikan kepada masyarakat secara tertulis dan dengan media informasi yang 
mudah diakses oleh masyarakat. Media informasi antara lain papan pengumuman, radio komunitas, dan media informasi lainnya. Laporan realisasi dan laporan pertanggungjawaban realisasi pelaksanaan APBDesa disampaikan kepada Bupati/Walikota melalui camat atau sebutanlain. Laporan pertanggungjawaban realisasi pelaksanaan APBDesa, disampaikan paling lambat 1 (satu) bulan setelah akhir tahun anggaran berkenaan. Ketentuan lebih lanjut mengenai Pengelolaan Keuangan Desa diatur dalam Peraturan Bupati/Walikota.

\section{HASIL DAN PEMBAHASAN}

\subsection{Tahap Perencanaan Pengelolaan Dana Desa}

Guna mendapatkan deskripsi tentang tahapan perencanaan pengelolaan dana desa di Kampung Bandonggwan, peneliti telah mewawancarai 5 (lima) orang responden dan hasil interpretasi atas data wawancara yang telah direduksi menunjukan bahwa masyarakat dilibatkan dalam tahapan perencanaan penggunaan anggaran Dana Desa. Hal ini ditunjukkan dengan terlibatnya Badan Musyawarah Kampung (BMKam) dalam penyusunan APBKam. BMKam di Kampung Bandonggwan merupakan representasi dari masyarakat Kampung Bandonggawan dengan jumlah 179 jiwa. BMKam bersama dengan perangkat Pemerintah Kampung Bandonggwan, bersama-sama bermusyawarah menyusun APBKam dan Penggunaan Dana Desa.

BMKam sendiri beranggotakan unsur-unsur masyarakat Kampung Bandonggwan yaitu Tokoh Agama, Tokoh Adat, Pemuda, Perempuan dan Pemuka masyarakat. Keterwakilan unsur-unsur pembentuk masyarakat ini menjadi representasi dari suara masyarakat yang memperjuangkan pemenuhan kesejahteraan warga Kampung Bandonggwan melalui pembangunan yang terprogramkan dalam APBKam.

Dalam perencanaan penggunaan Dana Desa Tahun 2020 yang disusun pada pertengahan tahun 2019 lalu, Dana Desa yang diterima Kampung Bandonggwan direncanakan untuk membiayai perbaikan jalan Kampung Bandonggwan dan perbaikan selokan serta membangun Kantor Pemerintah Kampung Bandonggwan yang sementara ini masih menggunakan rumah warga yang dikontrakkan. Adapun besar Dana Desa yang diterima Kampung Bandonggwan pada tahun anggaran 2020 adalah sebesar Rp. 202.764.131,--

\subsection{Tahap Pelaksanaan Pengelolaan Dana Desa}

Kajian pelaksanaan pengelolaan Dana Desa melibatkan 4 orang responden yang berasal dari Pemerintah Kampung Bandonggwan. Dan setelah direduksi hasil penelitian terinterpretasikan bahwa pengelolaan Dana Desa di Kampung Bandonggwan dilakukan oleh perangkat Kampung yaitu Kepala Kampung sebagai otorisator penggunaan anggran Dana Desa, Sekretaris Kampung yang merangkap sebagai Sekretaris Proyek Dana Desa, Kaur Keuangan sebagai Bendahara Dana Desa dan Kaur Pembangunan sebagai Pelaksana Proyek Dana Desa.

Meskipun dikelola oleh 4 orang perangkat Kampung, namun dalam setiap pelaksanaan proyek masyarakat Kampung Bandonggwan diberdayakan untuk turut serta dan mendapat manfaat dari ketelibatannya dalam proyek pembangunan fisik di kampungnya. Hal ini emang telah menjadi kesepakatan dalam perencanaan penggunaan anggran Dana Desa antara BMKam dan Pemerintah Kampung Bandonggwan.

Pengelolaannya memang diambil alih oleh pemerintah Kampung sesuai dengan tata cara pengelolaan yang diturunkan dari pusat. Sebagai pemenuhan unsur transparansi penggunaan Dana Desa, pengelola menginformasikan kemajuan penggunaan biaya secara berkala pada papan informasi yang dipajang di Kantor Kampung dengan maksud sebagai upaya penyampaian informasi serta pembelajaran bagi masyarakat dan pihak-pihak yang berkepentingan.

Dalam menjalankan proyek-proyek yang didanai dengan Dana Desa, sedapat mungkin pengelola melibatkan masyarakat di dalamnya dengan maksud menjadi sarana pelibatan sekaligus pembelajaran atau transfer pengetahuan supaya perlahan terbentuk peningkatan sumber daya manusia yang dimiliki Kampung Bandonggawan. Pengelola Dana Desa menyadari bahwa tugas rangkap yang dijalankannya cukup menguras waktu dan tenaga, namun semuanya dilakukan hanya untuk mendorong kemajuan dari kampung-kampung di Distrik Sausapor ini. Sebagai daerah pemekaran baru, banyak hal yang harus dibenahi, termasuk Sumber Daya Manusia. Pengelola Dana Desa sendiri tidak ada yang berlatar belakang keuangan, namun semua ingin belajar menjadi tahu untuk kesejahteraan banyak orang, dengan harapan bahwa kerja keras ini juga memotivasi generasi muda di Kampung Bandonggwan khususnya dan Distrik Sausapor serta Kabupaten Tambrauw untuk meningkatkan pengetahuan agar dapat kembali ke tanahnya dan memimpin. 
Dalam pelaksanaan pengelolaan Dana Desa, pihak pengelola merasa sangat terbantu dengan pendampingan dari Pemerintah Distrik Sausapor dan dari Kabupaten Tambrauw langsung baik dalam hal tatacara pengelolaan maupun dalam pelaporan.

Kondisi pandemik Covid - 19 sangat membatasi ruang gerak dan kinerja dari semua lini, termasuk kinerja pengelola Dana Desa./ Penggunaan dana desa yang dialihkan atau lebih tepatnya diprioritaskan pada dua hal yaitu: 1) pembangunan infrastrukrur swakelola dengan sistem Padat Karya Tunai Desa guna memperkuat daya tahan ekonomi desa dan masyarakat, dan

2) penguatan kesehatan masyarakat melalui upaya pencegahan dan penanganan Covid-19. Ini berarti bahwa rencana penggunaan Dana Desa yang ditetapkan di tahun lalu yang harus diimplementasikan pada tahun ini harus mengalami perubahan. Menyikapi hal ini maka pihak Pengelola Dana bersama Pemerintah Kampung Bandonggwan harus merevisi Anggaran Pendapatan dan Belanja Kampung (APBKam). Kebijakan ini ditempuh Pengelola dana desa bersama Pemerintah Kampung Bandonggwan di dasari pada Surat Edaran No. 8 Tahun 2020 tentang Desa Tanggap Covid-19 dan Penegasan PKDT yang dikeluarkan oleh Menteri Desa yang secara emergensi penggunaannya diatur oleh Peraturan Bupati mengenai pengelolaan keuangan pada situasi KLB.

Sebagai usaha konkritnya pemerintah Kampung Bandonggwan menggunakan dana desa untuk membiayai pelaksanaan sosialisasi tentang Covid-19, penyediaan disenfektan bagi masyarakat, penyediaan APD seperti masker secara cuma-cuma untuk masyarakat, dan penyemprotan disenfektan pada area publik di sekitar Kampung Bandonggwan. Selain itu proyek padat karya pembangunan sarana jalan dan selokan yang dikerjakan oleh warga dilakukan dengan menerapkan protocol Covid19 seperti menjaga jarak antara para pekerja hingga minimum 2 meter.

Pada mulanya masyarakat Kampung Bandonggwan yang terlibat dalam proyek padat karya sangat terbatas, namun pada masa pandemic ini warga masyarakat berbondongbondong melibatkan diri dalam proyek-proyek ini mengingat banyak pelajar yang menuntut ilmu di Kota Sorong kembali ke kampong untuk mengurangi pengeluaran akibat dampak Covid19, di samping itu banyak juga pengangguran karena lapangan pekerjaan semakin sedikit dan banyak usaha yang macet akibat pembatasanpembatasan yang ditempuh pemerintah untuk memutus rantai penyebaran Covid-19.
Pengalihan penggunaan dana desa ini sangat menopang kesejahteraan masyarakat Bandonggwan yang turut terimbas oleh kondisi pandemik ini. Karena letak geografisnya yang agak terisolasi, penyebaran Covid-19 memang tidak mengenai kampung ini, namun usaha pencegahan tetap dilakukan dengan memberdayakan dana desa.

Penggandatugasan yang terjadi pada aparat pemerintahan m,aupun pengelola Dana Desa pada Kampung Bandonggwan pada kondisi pandemic Covid-19 ini sebenarnya sangat membantu karena memudahkan koordinasi dalam masa social distancing, menekan biaya koordinasi dan memudahkan penyebaran informasi yang diperlukan secara mendadak.

\subsection{Tahap Pelaporan Pengelolaan Dana Desa}

Untuk mendapatkan deskripsi pelaporan pengelolaan Dana Desa, peneliti mewawancarai 4 (empat) orang responden. Dan dari wawancara tersebut diketahui bahwa peran dari pemerintah Kampung Bandonggwan sebagai pengelola Dana Desa adalah untuk mencatat penerimaan serta pengeluaran serta melakukan tutup buku setiap akhir bulan. Laporan yang dibuat secara manual sesuai dengan aturan dari Permendagri nomor 113 tahun 2014 pasal 35 ayat 2 .

Untuk laporan yang dibuat oleh pemerintah Kampung Bandonggwan sebagai pengelola Dana Desa adalah:

Buku kas umum

Buku pembantu pajak

Buku pembantu bank

Buku pemasukan

Sesuai dengan Permendagri Nomor 113 tahun 2014, laporan harus dibuat secara komputerisasi, dalam hal ini pengelola masih merasa kesulitan sebab tidak memiliki keahlian tersebut oleh karenanya pengelola membuat pencatatan manual dalam buku kas umum, buku pembantu pajak, buku bank, buku pemasukan. Keuntungan dari pencatatan manual adalah tidak ada ancaman kerusakan atau hilangnya data. Namun ntuk memenuhi tuntutan Permendagri Nomor 113 tahun 2014, pengelola Dana Desa di Kampung Bandonggwan sangat dibantu oleh pihak Distrik yang memiliki kemampuan komputer untuk melaporkan secara komputerisasi.

Dalam melaksanakan tugas serta kewajibannya dalam pengelolaan Dana Desa, Pemerintah Kampung Bandonggwan wajib memberikan laporannya kepada pemerintah diatasnya yakni Kepala Distrik Sausapor, maupun ke Bupati Tambrauw. Disamping itu pemerintah Kampung Bandonggwan dalam mempertanggungjawabkan kegiatannya wajib menyampaikan kepada masyarakat lewat BMK. 
Pelaporan Dana Desa sebenarnya tidak terpisahkan dengan penyampaian informasi APBKam, hanya saja terdapat laporan khusus yang membedakan dengan dana-dana yang lain. Laporan ini bernama laporan realisasi Dana Desa. Penyampaian laporan realisasi Dana Desa dilakukan paling lambat minggu keempat bulan Juli tahun anggaran berjalan untuk semester satu dan paling lambat minggu keempat bulan Januari tahun anggaran berikutnya untuk semester dua.

\section{KESIMPULAN}

Bertolak dari uraian hasil penelitian dan pembahasannya, penelitian ini berkesimpulan bahwa pengelolaan Dana Desa yang dilakukan di Kampung Bandonggwan Distrik Sausapor Kabupaten Tambrauw belum optimal demi kesejahteraan rakyat karena minimnya Sumber Daya Manusia yang dimiliki Kampung Bandonggwan khususnya dalam keahlian perencanaan, akuntansi dan komputerisasi. Pandemik Covid-19 menyebabkan Pengelola Dana Desa dan Pemerintah Kampung Bandonggwan untuk merevisi APBKam dengan memprioritaskan penggunaan dana desa untuk mempertahankan taraf ekonomi masyarakat dan upaya pencegahan penyebaran Covid-19. pengelolaannya dapat berjalan karena didukung oleh pendampingan dari Pemerintah Distrik Sausapor maupun Pemerintah Kabupaten Tambrauw.

Untuk mengoptimalkan pengelolaan Dana Desa terkhusus dengan karakteristik daerah pemekaran baru maka penelitian ini menyarankan kepada Pemerintah Kabupaten Tambrauw maupun Pemerintah Distrik Sausapor untuk memprogramkan kegiatan peningkatan kapasitas pemerintah kampung dalam penguasaan komputer dan pelatihan akuntansi/pembukuan dan perencanaan program guna menyiapkan kader pengelola administrasi dan keuangan di setiap kampung dalam wilayah pemerintahannya.

\section{DAFTAR PUSTAKA}

[1] Farida, 2015."Transparansi dan Akuntabilitas Pemerintah Desa dalam Pengelolaan AnggaranPendapatan d an Belanja Desa (APBDes) “ dalam Jurnal Ilmu \& Riset Akuntansi Vol. 4 No. 5

[2] Irma, Ade. 2015.“Akuntabilitas Pengelolaan Alokasi Dana Desa (ADD) di Kecamatan Dolo Selatan, Kabupaten Sigi"dalam e-jurnal katalogis, volume 3 nomor 1, januari 2015.
[3] Mardiasmo. 2004. Akuntansi Sektor Publik. Yogyakarta: Andi Offset

[4] Peraturan Menteri Keuangan Nomor 241 Tahun 2014 tentang Pertanggungjawaban Anggaran Transfer

[5] Peraturan Menteri Keuangan No. 247 Tahun 2015 tentang Tatacara Pengalokasian, Penyaluran, Penggunaan, Pemantauan dan Evaluasi Dana Desa

[6] Peraturan Menteri Keuangan Nomor 93 Tahun 2015 tentang Tatacara Mengenai Pengalokasian, Penyaluran, Penggunaan, Pemantauan Dan Evaluasi Dana Desa

[7] Peraturan Pemerintah 22 Nomor 8 Tahun 2016 tentang Dana Desa Bersumber dari Anggaran Pendapatan dan Belanja Negara

[8] Peraturan Pemerintah Nomor 43 Tahun 2014 tentang Pelaksanaan Undang Undang Desa

[9] Permendes Nomor 3 Tahun 2015 tentang Pendampingan Desa.

[10]Permendesa Nomor 2 Tahun 2015 tentang Pedoman Tata Tertib Mekanisme Pengambilan Keputusan Musyawarah Desa

[11] Surat Edaran Menteri Desa No. 8 Tahun 2020 tentang Desa Tanggap Covid-19 dan Penegasan PKDT 